\title{
The shrinking democratic space in India: uncivil society and an illiberal state
}

Edition 1, 2020

Associate Professor Sarbeswar Sahoo

DOI: 10.37839/MAR2652-550X1.11

Deadly clashes have broken out this month in India's capital New Delhi between supporters and opponents of the Government's changes to citizenship laws. The amendment to the Citizenship Act of 1955 - brought into force on December 12 last year - provides Indian citizenship to Hindu, Sikh, Buddhist, Jain, Parsi, or Christians from Afghanistan, Bangladesh or Pakistan who faced persecution and entered India before December 31, 2014. The Act does not provide citizenship for Muslims in similar circumstances.

Protests have broken out across India led by those who argue the Act now undermines secular notions of citizenship by defining it as based on religion; and violates the constitutional principles of equality and non-discrimination. To date, dozens of people have been killed.

During the last six years, the government led by Prime Minister Narendra Modi of the BJP, has implemented its Hindu nationalist agenda through various policies. India's civil society has been heavily polarised along ethno-religious lines and its autonomy is being systematically undermined and delegitimised. While it is true that the space for democratic civil society in India is shrinking, this is not something unique to the incumbent BJP-led National Democratic Alliance (NDA). As the discussions show below, all governments, irrespective of their ideology, have, at different times and in different ways, tried to depoliticise, control and also often 
repress the civil society.

Although the reasons for doing so have varied, this paper will show what is common to the BJP and the opposition Congress Party, is their effort to depoliticise and control the civil society and their commitment to advancing the neoliberal regime in India - despite adhering to contrasting ideologies. In particular, the Modi government is partly using instruments being made available to him by the previous Congress governments, which were secular in nature but sowed some of the seeds for authoritarian tendencies of the Indian state.

\section{Civil society under pressure}

The BJP-led NDA government came to power in the summer of 2014 and was reelected in a landslide in 2019, with Modi promising to bring achhe din (good times) for all. However, in the last six years, his government has done very little to prove that it is committed to the principle of inclusive development - sabka saath, sabka vikas (together with all, development for all). On the contrary, the government has taken a very strong authoritarian approach to deal with dissenting voices within civil society.Under Modi, the BJP-led NDA has aligned itself (politically and financially) to a group of organisations within civil society that advance its ideological and political projects, particularly the Rashtriya Swayamsevak Sangh (RSS). The RSS is one of the largest civil society organisations in India and has a Hindu nationalist agenda.

Hindu nationalism has made itself felt in India recently in a variety of ways, including Hindu vigilante groups killing Muslims and others for their food habits and accusing young Muslim men of luring young Hindu women and converting them for marriage. Instead of acting against such violations of law and order, the government and its leaders have provided open moral and political support. One the one hand, the state is providing active politico-economic and legal support to some sections of civil society. On the other, it is actively monitoring, constraining and censuring the activities of civil society groups that question the state and its policies. 
A historical analysis of the state-civil society relationship shows that while this has intensified under the BJP-led NDA regime of Prime Minister Modi, it is not unique to it.

\section{State and civil society after Independence}

On the $15^{\text {th }}$ of August 1947 India officially became independent, ending a long period of British rule. India's democratic Constitution provided for freedom of speech, freedom of association and freedom of press, which served as the foundation for the development of a free public sphere.

Considering the prevalence of mass poverty, illiteracy and underdevelopment, the Indian state led by Prime Minister Jawaharlal Nehru took up a major role. The dominant belief was that 'a strong state was the only way a mass society - which was largely illiterate and poor and which held strong ethnic and caste loyalties and was hence "incapable" of thinking for the country - could be adequately governed'. The state thus followed a centralised mode of planning and governance; and took the form of a 'developmental state', intervening in the economy, planning and guiding its growth, and actively promoting the welfare of its population.

The principles of self-rule (swaraj) and self- reliance developed by independence leader Mahatma Gandhi had a major influence on Nehru and postcolonial state building. His government invited Gandhian organisations to play a leading role in national reconstruction and development of village communities and civil societies. Through its "Five Year Plans", the government introduced community development programs and provided large funding to Gandhian organisations that worked in community and rural development. Thus, during Nehru's period, Gandhian NGOs played a major role in providing welfare and relief and shared a strong and cooperative relationship with the state. 


\section{State and civil society under Indira Gandhi}

After the death of Nehru, particularly in the late 1960s, India went through a period of political and social instability. A large number of political leaders with criminal backgrounds were elected, there was ineffective enforcement of the rule of law, rising corruption scandals and increasing deinstitutionalisation. Furthermore, the emergence of the Maoist Naxalite movement challenged the legitimacy of the state. To control the political situation, in 1975 Prime Minister Indira Gandhi suspended the rule of law and imposed Emergency rule, which suppressed civil society and undermined the legitimacy of democratic political institutions. Despite this, several grassroots civil society movements emerged in different parts of India to resist the Prime Minister's authoritarian rule.

Gandhian activists like Jayaprakash Narayan (known as JP) strongly opposed Prime Minister Gandhi's rule and mobilised Gandhian workers, NGOs, students and trade union leaders to become actively involved in what he referred to as Sampurna Kranti or 'total revolution' to bring political change. More than 300 Gandhian organisations joined the JP movement. JP was also joined by Hindu nationalists such as the RSS and Jan Sangh, and another famous Gandhian, Morarji Desai. Desai played a major role in mobilising the middle classes in his home state of Gujarat. This rising grassroots political mobilisation eventually transformed the nature and capacity of the state and civil society.

\section{The regulation and surveillance of civil society organisations receiving foreign funding}

Realising the role that civil society organisations and peoples' movements had been playing in subverting her government, Prime Minister Gandhi increased control over NGOs and regulated foreign funding. In this context, the case of Asia Foundation, a 
United States based agency, became relevant. India's Ministry of Home Affairs had granted permission to Asia Foundation to set up an office in India to provide assistance to various NGOs. It was, however, revealed that the Foundation was funded by the US Central Intelligence Agency. Following this shocking disclosure, the government suspended the Foundation's activities in India, expelled many foreign missionaries and foreign NGO officials, accusing them of subversive activities, and enacted the Foreign Contribution Regulation Act (FCRA) in 1976.

The Janata Party led by Desai came to power in 1977. Considering the role civil society organisations and various peoples' movements had played during the Emergency rule period, Desai actively encouraged civil society work and NGO involvement in rural development programs. The government vastly increased funding for civil society organizations (CSOs) and provided bureaucratic support. Taking advantage of this, Hindu nationalists expanded their activities in different parts of India. However, although the Janata government actively promoted NGOs and other civil society actors, its policy did not last long.

Indira Gandhi returned to power in 1980 and again increased control over civil society organisations. She amended the FCRA in 1984, making it mandatory for all NGOs receiving foreign funds to register themselves with the Home Ministry. This helped the government monitor NGO activities and empowered it to ban any organisation from receiving foreign contribution, if it was deemed to political instead of neutral. Indira Gandhi also appointed the Kudal Commission in 1981 in retaliation against the Gandhian NGOs that had supported the JP movement during the Emergency rule. The Commission made allegations about missing funds against 945 Gandhian NGOs.

\section{Civil Society Organisations and}




\section{depoliticised development}

Following the assassination of Mrs. Gandhi on 31 October 1984, her elder son Rajiv Gandhi came to power with a massive mandate in 1984 General Election.

Rajiv Gandhi understood the problems associated with the state-led, top-down approach to development. He actively promoted NGOs and other civil society organisations to deliver services and act as watchdogs. The Government's Planning Commission identified NGOs as effective service delivery mechanisms and active partners in development. The Rajiv Gandhi government increased funds available to NGOs and civil society organisations that worked for social development. Such promotion of CSOs also helped the government to continue to depoliticise development discourse and to suppress the 'too political' elements within civil society that were considered to be necessary for the implementation of future neoliberal policies.

\section{Economic liberalisation and civil society organisations}

With the liberalisation of Indian economy, the World Bank and the International Monetary Fund (IMF) became interested in poverty alleviation. Rigid bureaucratic state and corruption in the government were recognized as major factors responsible for the high prevalence of poverty and failure of development. In addition, India adopted the structural adjustment policies of the World Bank and the IMF in 1991, which resulted in the rolling back of the state from many areas of social welfare. This opened up space for increased civil society activity. Direct aid to committed citizens and NGOs engaged in community development was regarded as highly efficacious option for realising the development objectives.

Therefore, the amount of foreign funding to NGOs increased significantly. However, following structural adjustment conditionalities, the Indian government agreed to 
promote the NGO sector and limit the forms of agitational (andolanatmak) civil society as a part of the global agenda of good governance. This broadly restricted CSOs to depoliticised service delivery activities, resulting in what Neema Kudva calls 'NGO-ification of civil society' in India. Today there are more than three million NGOs in India, making it 'the unofficial NGO capital of the world' .

\section{Civil society under the Congress-led UPA regime}

Two paradoxical developments occurred during the decade long Congress-led United Progressive Alliance (UPA) government that had significant implications for civil society.

One the one hand, the government followed a pro-poor agenda and actively promoted civil society groups as partners of development. It created a special body called the National Advisory Council (NAC) consisting of ex-bureaucrats, academics and civil society activists to advise the government on implementing its pro-poor agenda codified through the common minimum program. The NAC played a major role in facilitating the relationship between the government and the civil society. Specifically, it followed a rights-based approach and played an instrumental role in drafting several key pro-poor laws like the Right to Information Act, the National Rural Employment Guarantee Act, the Forest Rights Act, the Right to Education Act and the Food Security Act.

On the other hand, the government was strongly committed to the implementation of neoliberal economic policies in India. In order to achieve and maintain high economic growth, the government invited multinational companies and facilitated their entry into resource rich regions. Acquisition of land for infrastructural development, special economic zones and mining projects (for example, by POSCO and Vedanta) created massive displacements and dislocations. This eventually resulted in the rise to large-scale protests against the exclusivist and exploitative 
policies of neoliberalism. Knowing that NGOs and other civil society groups play a major role in leading these anti-state and 'anti-development' protest movements, the government enacted the new FCRA in 2010 to tighten its control over civil society and restrict its role to depoliticised service delivery activities.

\section{The Government of Prime Minister Modi and the shrinking of the civic space}

Despite being informed by different ideology to the Congress party, the BJP government also strongly followed neoliberal policies. It sought to promote rapid industrialisation and economic development through its flagship program called 'Make in India'. However, while implementing these policies, it also finds oppositional/politicised civil society groups an obstacle to development and nation building. The BJP-led government has therefore acted heavily against such organisations and movements. During the BJP regime, neoliberal policies have become heavily tied to the nation-building process and anyone opposing such policies is accused of being involved in anti-national activities.

In 2014 amid a slowing economy, a leaked report by India's Intelligence Bureau reportedly accused NGOs of 'reducing India's GDP by a staggering 2-3 per cent per annum, by campaigning against projects that the Indian government argued to be integral to economic growth'. The report also accused 'foreign funded' NGOs such as Greenpeace, Amnesty, Cordaid and ActionAid of 'serving as tools for foreign policy interests of western governments' by sponsoring campaigns to protect the environment or support human rights.

Not long after the BJP government came to power, it made the Foreign Contribution (Regulation) Act (FCRA) stricter and:

".. increased the reporting requirements for CSOs and made it compulsory for all registration applications to be made online. Under the amended rules, all 
organisations that receive funding from foreign sources must also publish annual audit statements of the funds, stating what the funds were used for, on their official website or a website specified by the central government. The statements must include details of the donors, amounts received, and dates donations were received. In addition, Indian banks are compelled to report any funds received from foreign sources within 48 hours".

This built on changes made by the Congress-led UPA government, which in 2010 made it compulsory for NGOs to register with the Ministry of Home Affairs if they intend to receive foreign funding. This empowered the Ministry 'to suspend, cancel or freeze the FCRA account of an organisation if it is determined that the organisation violated any provision of the FCRA'.

The further tightening of the requirements by the current Government makes it easy for the government to target CSOs that are critical of its policies and visions of development, especially CSOs that work on human rights, environment, climate change, workers' rights and so on. For example, in 2016 the Ministry of Home Affairs (MHA) cancelled the registration of the Lawyers Collective, an NGO that works on human rights issues. The Lawyers Collective and its founders were accused of misusing funds received under the FCRA. Similarly, in April 2015, the MHA ordered the freeze of the bank accounts of Greenpeace India and accused the organisation 'of engaging in activities that were against India's economic interests, threatening national security and inciting protests'. Accusing the Greenpeace activist Priya Pillai of being involved in 'anti-national activities', the NDA government prevented her from travelling to London in January 2015.

A report by Civicus shows that between 5 May and 9 June 2015, the MHA cancelled the registration of 4,470 CSOs for violating the FCRA. Furthermore, in 2016, the government cancelled licences of around 20,000 of 33,000 NGOs after they were found to be violating various provisions of the FCRA. This shows how the current government has used the FCRA as an instrument of repression and surveillance of civil society. 
The government has also used various colonial era laws (like sedition) to intimidate, target and harass CSOs and human rights activists. Specifically, the government has targeted those who criticised its policies and programs and has labelled them as 'anti-national'. Even freedom of expression in the university space is heavily constrained and the students' community is being repeatedly targeted. For example, the government has accused students at Jawaharlal Nehru University, Hyderabad Central University, Jamia Milia Islamia and various others of being involved in antinational activities because the students opposed the government's anti-minority agenda.

\section{Concluding Remarks}

The above discussion shows that there is currently a severe crackdown on the civic space in India. While such a crackdown is not a recent trend, it has certainly intensified during the last six years of the Modi-led government.

The state and civil society enjoyed a very cooperative and constructive relationship during the Nehruvian period immediately after Independence, but the subsequent government of Indira Gandhi imposed significant restrictions and repression on civil society through the enactment of the FCRA. Various successive governments, including the so-called secular and progressive Congress-led UPA government, have also utilized the FCRA as an instrument to coerce and constrain the civil society. The UPA government while on the one hand promoted state civil society relationship through the formation of NAC and enacted rights-based legislation to advance the interests of the poor and marginalized communities; on the other hand, it enacted the new FCRA in 2010 by replacing the 1976 Act to tighten its control over politicised elements within civil society that were seen as obstructing the spread of neoliberal capital.

Similarly, the BJP-led Modi government has been heavily committed to neoliberal policies. To smooth the path for neoliberal capital, soon after coming into power, the 
Modi government amended the 2010 FCRA of the UPA government and introduced the severest restrictions yet on civil society. What this shows is that the Modi government is partly using instruments being made available to him by the previous Congress governments - which were secular in nature but sowed some of the seeds for authoritarian tendencies of the Indian state. The consequence of this has been that the space for autonomous civil society organisations, especially those working on human rights, environment and climate, indigenous rights, workers' rights and minority rights, is shrinking.

Furthermore, the BJP-led state, guided by the conservative Hindu nationalist ideology, has played a major role in polarising the civil society space and criminalising the activities of minorities. In particular, it has followed a highhanded approach in dealing with organisations that do not confirm to its visions of development and nationhood - such organisations are branded as anti-development and anti-national. Instead, the government has been closely working with those sections of the civil society that support its ideological project of making India a Hindu nation. By providing financial and political support to such organisations, the government has been implementing its policies and projects as well as enhancing its public legitimacy. Such active support from the state has empowered these organisations to pursue agendas that undermine various constitutional values.

In India today, an illiberal state (led by the NDA regime) has collaborated with an uncivil society (the RSS and its affiliates) to advance the neoliberal project and maintain political hegemony. The consequences of this are the shrinking of the civic space and the undermining of the values of pluralism, freedom, autonomy and democracy in India.

Image: Students protesters in New Delhi against in privatisation of education, November, 2019. Credit: Sandeep Jeengar/Shutterstock 